\title{
Attributes and references to honey bees (Insecta; Hymenoptera; Apidae) and their products in some Asian and Australian societies' folkloristic domains
}

\author{
V. B. Meyer-Rochow (D)
}

\begin{abstract}
Background: References to insects in myths, stories, and idioms can be found in almost any culture, but with regard to references involving honey bee species in the Asia-Australian region, little information is available. Such references to bees can be highly informative by revealing attitudes of admiration, fear, ignorance, or even revulsion towards these insects.

Results: The subject is briefly reviewed and examples of references to bees of selected cultural communities are given. Although folkloristic references to honey bees were found to be mostly positive highlighting fearlessness, cleverness, and industriousness of the bees, some also touch upon their ability to cause pain.

Conclusions: Owing to the decreasing contacts and increasing alienization regarding insects generally, a plea is made to collect whatever information is still available about references to bees in songs, myths, stories, proverbs, and idioms and to compare such uses from different regions, e.g., North and South Korea. This would support other fields of research aiming to discover and to describe cultural relationships, migrations, and contacts between different peoples of the Asian/Australian region.
\end{abstract}

Keywords: Socio-linguistics, Ethno-entomology, Insect appreciation, Cultural role of bees

\section{Background}

The evolutionary history of Apidae, i.e., social honey bees generally and that of the Western honey bee Apis mellifera in particular is far from being resolved. Africa, long championed as the place where social bees evolved (Manning 1952; Wilson 1971), is still the front runner for some researchers (Whitfield et al. 2006; Tihelka et al. 2020), while others who conducted genome sequence comparisons conclude that honey bees originated from Asia and not Africa (Walberg et al. 2014). Yet, a Middle Eastern origin also has its supporters, who based their conclusions on mitochondrial genome analyses (Garnery et al. 1992) and evidence for a North African or Middle

Correspondence: meyrow@gmail.com

Department of Plant Medicals, Andong National University, Andong 36729, Republic of Korea
East origin was presented by Cridland et al. (2017). Even the view that the genus Apis originated in Europe and spread from there into Africa and Asia is entertained and supported by specimens entombed in Baltic amber (Kotthoff et al. 2013). The situation is complex and confusing and no universally acceptable conclusion, as Borst (2015) aptly summarizes, has yet been reached.

What is much less in doubt is that social bees were not around for millions of years during which flowering plants of the angiosperm lineage began to dominate the terrestrial flora. The origins of the latter have been suggested to roughly coincide with the beginning of the Cretaceous Period, i.e., approx. 125 million years ago (Culliney 1983; Neige 2015), while social bees did not appear until about 30 million years ago in the Oligocene era of the Tertiary (65-2 million years in the past). This

(c) The Author(s). 2021 Open Access This article is licensed under a Creative Commons Attribution 4.0 International License, which permits use, sharing, adaptation, distribution and reproduction in any medium or format, as long as you give appropriate credit to the original author(s) and the source, provide a link to the Creative Commons licence, and indicate if changes were made. The images or other third party material in this article are included in the article's Creative Commons licence, unless indicated otherwise in a credit line to the material. If material is not included in the article's Creative Commons licence and your intended use is not permitted by statutory regulation or exceeds the permitted use, you will need to obtain permission directly from the copyright holder. To view a copy of this licence, visit http://creativecommons.org/licenses/by/4.0/ 
discrepancy prompted Charles Darwin to make his famous utterance of the "abominable mystery" of the evolution of angiosperms (Briggs 2018, https://www.bbc.com/ news/science-environment-42656306 ), and we can extend that to include the co-evolution between inflorescences and honey bees.

However, what is in no doubt at all is the long relationship between humans and honey bees and their products, principally honey, wax, and mead which goes back to the pre-neolithicum 8000 years ago as documented by rock wall paintings from the Stone Age in Spain (Kritsky 2017). The close association of A. mellifera with Neolihic farming communities in Europe, North Africa, and the Middle East "dates to the early onset of agriculture and may provide evidence for the beginning of a domestication process" (Roffet-Salque et al. 2016; Cailloce 2019). Even the origin of the English word "medicine", according to some can be traced to a product of the honey bees, namely "mead", i.e., the fermented honey (Anonymous 20142021 http://www. mountaindragonmazery.com/meadlore.html).

For the South and East Asian as well as Australian realm, the situation regarding beekeeping and honey bee appreciation is somewhat different as the A. mellifera was a "late-comer" and introduced to these regions only in the last several hundred years. For most countries, precise dates of the arrival of $A$. mellifera are not available, but for Korea, it is accepted that beekeeping greatly benefitted from instructions given by a German missionary of the name Kuegelgen, who between 1914 and 1918 wrote an instruction manual in the Korean language how to keep A. mellifera and harvest its honey and wax (Jung 2014). Of course, the earlier absence of the Western honey bee does not mean that people in South and East Asia or Australia did not appreciate wax and honey and the numerous health benefits of the latter, for there were local bee species like stingless meloponine bees and species of the genus Apis such as the small and tropical $A$. florea and $A$. andreniformis, the South-East Asian species $A$. koschevnikovi, and the Philippine $A$. nigrocincta, as well as the widespread $A$. cerana and the large rock bees $A$. dorsata of South Asia and A. laboriosa of the Himalayan region whose products were extensively used.

The issue of the total number of social honey bee species is complicated and while about 20,000 species of bees are thought to exist, only eight species of honey bee with a total of 43 subspecies are recognized (Engel 1999). With regard to the folkloristic appreciation of bees in this paper, the taxonomic aspect was not deemed to be of major importance as the local people, themselves, often did not distinguish between different species of bees when referring to them in their stories, idioms, or proverbs.

\section{Honey bee folklore in some regions of the Asia-Australian realm}

The stories and the information reported in this paper are the results, if not mentioned otherwise, of conversations and interviews with local people of their respective domiciles. While the arrival of the Western honey bee $A$. mellifera was nearly universally welcomed, because of its greater yield and easier management than the local species, there are some notable exceptions. The Kalam people of the Kaironk Valley in Papua New Guinea made use of the local stingless bees of the region and consumed their honey, which they termed "bumnm," but they utilised neither the larvae nor the honey of the introduced Western bee $A$. mellifera, which they called "cp-tmegbojm." Note that the English meaning of "cptmeg" is "ghost" and that the word used to be applied also to people of Western origin (Bulmer, pers. Comm., 1978; Pawley and Bulmer 2011).

In European languages and cultures, one finds a wealth of references not just to honey bees, be it in the context of myths, songs, or idioms (Meyer-Rochow and Kejonen 2021) but bees, generally, including bumblebees. Yet, in spite of these insects' painful (and sometimes even lethal) sting, they are held in comparatively rather high esteem-quite in contrast to wasps and hornets, which are usually feared and despised (Meyer-Rochow and Kejonen 2021). In the traditional societies of Asia and the Australo-Pacific region bees would undoubtedly also have been mentioned in some legends, songs, proverbs, and other cultural contexts, but a systematic study of such uses appears not to have been carried out to date. Information regarding the old Vedic tradition has it that honey bees were termed "frail cows" and that the combs were considered to be made of the skin or of vegetable substance. A link to the ancient Greek bull cult and Cre$\tan$ mythology is provided by the old Vedic statement that the first bee swarm emerged from a dead bull (Anonymous 2021).

In connection with the Australian Aborigines more than 30 totemic groups are listed by Spencer and Gillan (1899) and specifically honey bees are mentioned by Berndt and Berndt (1964). The Pintupi of Central Australia has several orally transmitted but as yet unpublished stories about native stingless meloponine bees of the genus Austroplebeia sp. and old "honey hunters" hand down their wisdom on how to track down the bees and find their nest inside a hollow tree to the younger generation. Finding the bees' nest involves investigating spider webs for bee remains (Fig. 1), poking sticks into holes of a tree (Fig. 2) and then smelling them to detect the odor of honey, listening to possible sounds inside a tree and catching a bee and attaching to it a light and fluffy bird feather to make it easier to see into which direction it is flying away. 


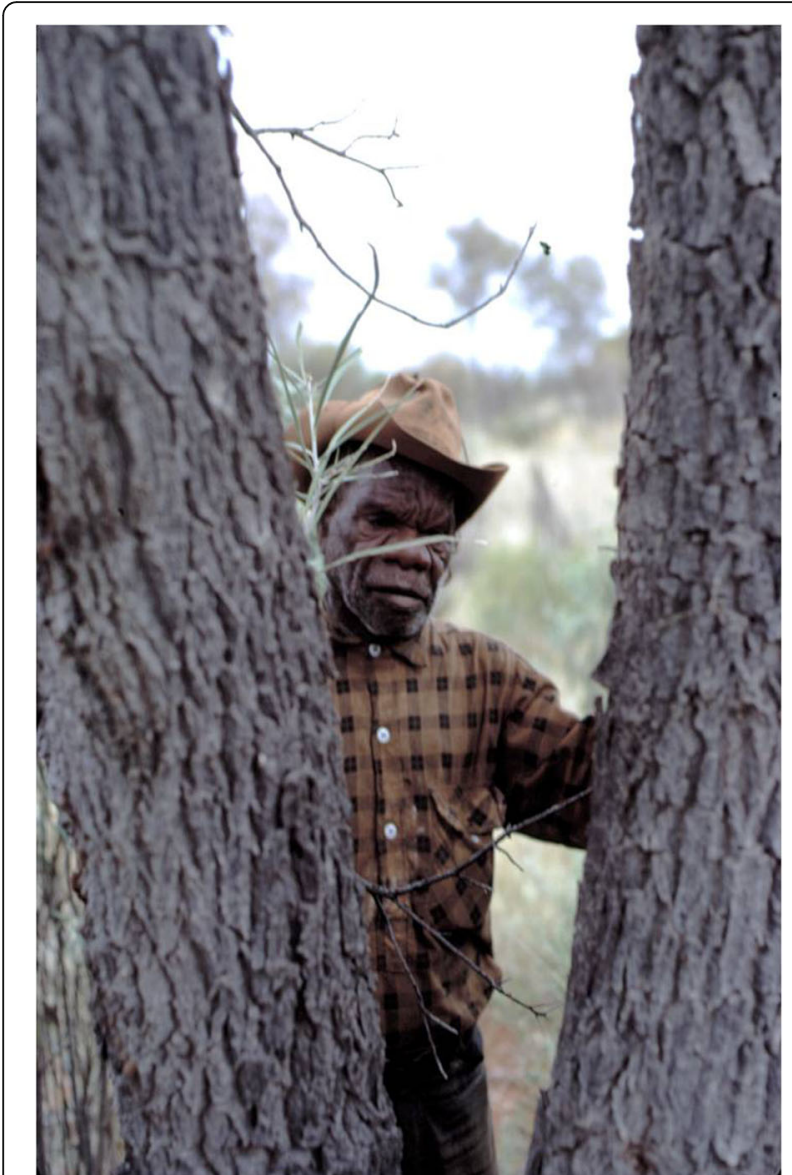

Fig. 1 Central Australian Walbri elder Mr. Darbie Jambijimba examining a spider web to identify possible debris of meloponine stingless honey bees to locate their next. Photo credit: the author

First reported by Megu et al. (2018), the Adi-people of North-East India's Arunachal Pradesh know several stories about honey bees generally (e.g., A. mellifera, A. cerana, A. dorsata) and have long recognized a connection between bees and a good rice harvest. For example, they say: "Yiine tuglinge peyig gela, ali tugling e peyig lenkai". Adi people express with this saying that maturing rice grains are the result of copulations between bees and the rice flowers in the paddies, from which the bees collect pollen. As children resemble their parents, the Adi noticed that the pale yellow color of the ripening grain resembles the color of the head of a bee, indicating a close relationship between bee and rice grain.

A story told by the Adi people to their youngsters is this:

A long time ago, two friends, a honey bee and a firefly, travelled to a foreign land. While flying together the bee struck its nose and head on a rock and started producing a buzzing sound. Until this day bees are producing this buzzing sound, but fireflies

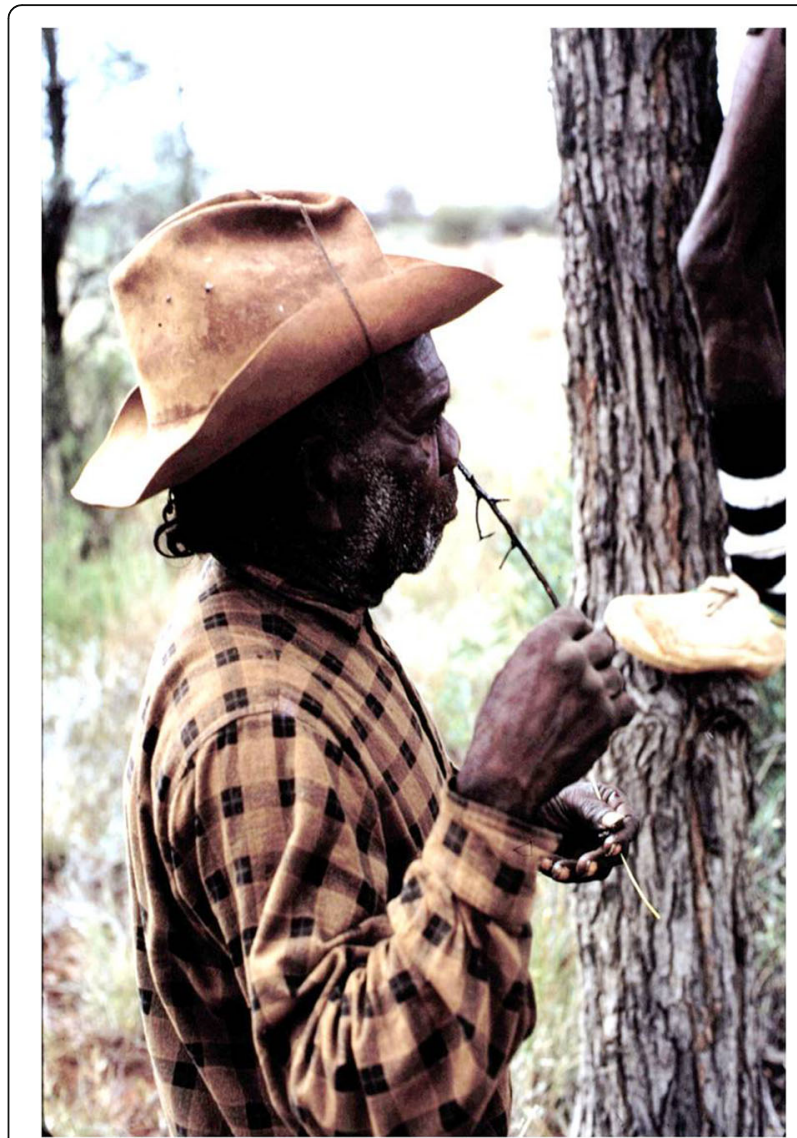

Fig. 2 Central Australian Walbri elder Mr. Darbie Jambijimba smelling a stick he had poked into a hole in the tree to find out if the tree contains honey bees. Photo credit: the author

produce no sound at all when they are flying, for they have light at night to see by. The Adi believe that the buzzing sound of a fling bee stems from the accident the bee had in a foreign land a long time ago.

In another story by the Adi, the goddess "Kine-Nane" had sown the first grain seeds and the grain had begun to grow up. Meanwhile, a bee had come as a guest and visited the agricultural field. The great beauty of the blooming grain was highly attractive to the bee and it began to have a love affair with the blooming grain. The plant became pregnant and ripened, producing mature grains. This story resembles the earlier one and testifies to the link between bees and fruit.

In yet another story of the Adi that features a bee, once upon a time three friends, namely a sunbird, a deer, and a honey bee, stayed together when the bird said to the others:

Listen, my two friends. I have chewed five mango seeds within no time. Upon hearing this, the deer 
burst out with laughter, so that its muzzle became rough and irregular. The bee on the other hand began to think and think very deeply how such a small bird could possibly chew five such very large mango seeds. So, the bee's belly became constricted and quite narrow. The Adi believe the muzzle of the deer became rough after this incident and the bee's belly became narrow and constricted.

Because quite often clear distinctions are not made between wasps and bees, it is possible that this story (and perhaps others as well) could have been inspired by wasps rather than bees. In Japan, for instance, "hachinoko" are sold as edible "bee larvae" Fig. 3), but in reality, they are wasp larvae and should be called "suzumebachi no ko." To be precise and to clearly distinguish bee from wasp, the former ought to be referred to as "mitsubachi" ("honey bee"). In Japan, for instance, the proverb "abu-hachi-torazu" uses the words 䗆 (abu) means horse-fly and 蜂 (Hachi) means bees or wasps. It is uttered from a spider's perspective and is used when someone cannot decide between two options and then has no luck with either. In another proverb that refers to “hachi” (蜂) and goes きつ面に蜂 (nakittsura nihachi) the latter are treated as bad insects that sting. This

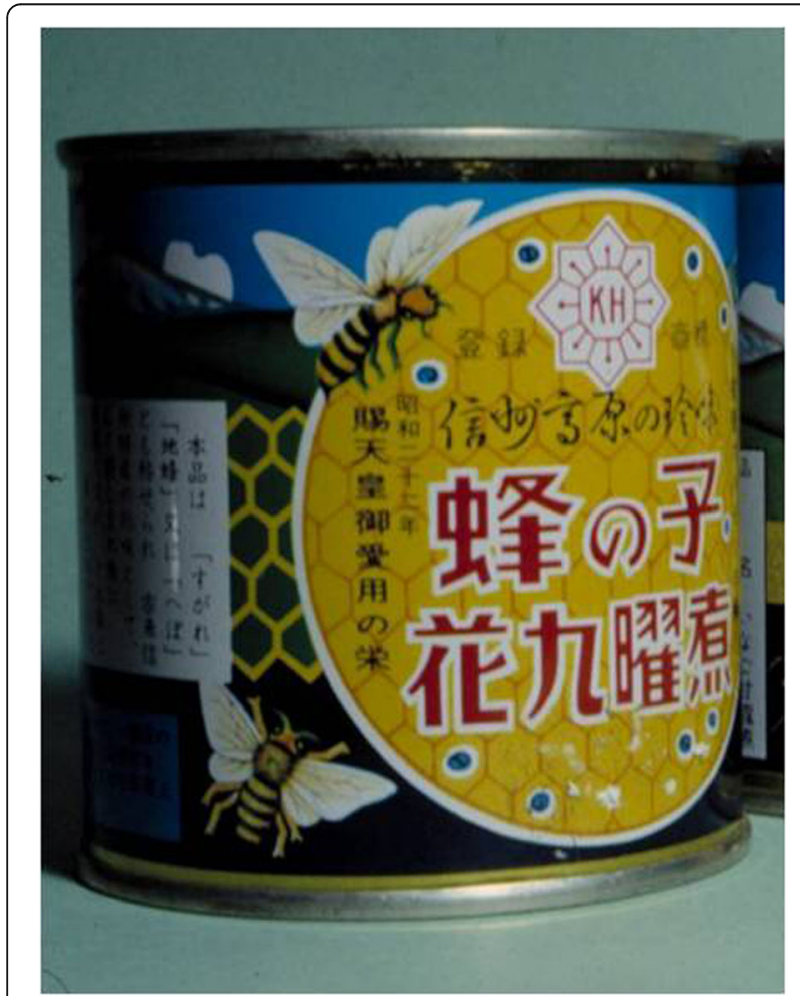

Fig. 3 Canned edible insects in Japan, sold under the name "hachinoko," meaning bee larvae, although the product actually consists of wasp larvae. Photo credit: the author proverb suggests that when you are unhappy and exhibit a crying face, more unhappiness will arrive.

A famous story in Japan is Sarukani Gassen. It deals with a freshwater crab whose parents were killed by a mean-spirited monkey, but the crab's revenge on the monkey depended on the cooperation with bees, which attacked the monkey and stung it. In fact, the idea that bees help people who have helped the bees before can be found in several local bee stories in Japan. In Yamagata Prefecture, for example, people talk about a man who helps a bee that is being "bullied" (troubled) by children. Later, the bee helps the man answering a question that was posed to him so that he can marry the daughter of the landowner. A very similar story, involving a bee, is also known from Oita Prefecture.

The Tangsa tribals of North-east India have a story about $A$. florea (a species they know by the name 'nyahbi'). Although these bees live for many months, unable to count and track on how long they have lived and worked, they claim to have lived only for a day. As a metaphor, this story is used to characterise people who would just sit around idly, procrastinating works every time without a worry or concern of the time and the days wasted. This is how the Tangsa compare such a person with this bee, namely how the latter say they have lived only for a day when in fact they have been around for many months or even years. A. cerana and $A$. mellifera (local names: Nyahkaai and Ngahkhing) are referred to by the Tangsa when they see a military parade, in which soldiers walk with synchronized hand, leg, and body movements. This reminds the onlooker of the synchronized flapping of wings and legs of these bees around their hives.

A song sung by the Apatani of North-East India (Fig. 4) to their children as a lullaby in their language is Taiyan yang yangtaiyan yang yang. The lyrics are

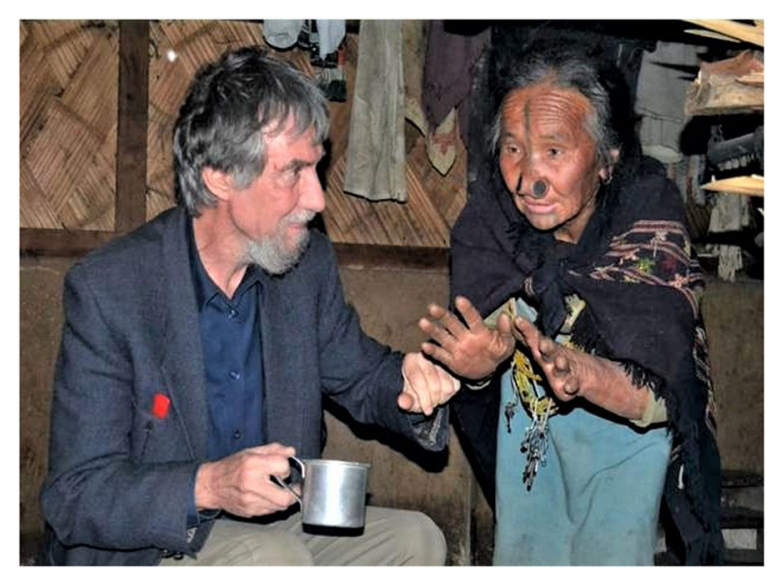

Fig. 4 Elderly Apatani lady (North-East India), telling the author stories about insects and insect myths. Photo credit: K. Megu 
"Yakhiiyakhii; Atoatomallosimallosi; Taiyanpereyandokeyandoke". In English: Taiyan (honeybee) yang (buzzing of bees) and the lyrics translate to "Bees have come and are flying over the roof of the house."

This song represents a view of the world from the bees' perspective; the way bees look at us and the world from above. Although this rhyme does not have any specific significance in relation to the history of the Apatani culture or traditions, it is popular with little children as a joke, rhyme, and lullaby. In the neighboring state of Nagaland, it was believed that knowledgeable elders can predict earthquakes by observing the movements of the bees. Before an earthquake strikes unfamiliar behaviours were said to be noticeable among bees during swarming or when leaving their hives and this would make the villagers aware of an imminent earthquake.

In North Korea (Fig. 5), officially known as "DPRK," the author of this paper collected several proverbs that featured honey bees and were used in connection with distinct human behaviors (Meyer-Rochow 2016). For example, one could hear people say:

1. 벌도 왕벌이 있고 기러기떼도 길잡이가 있다. $(\mathrm{N})$

Beol do woangbeoli it-go gireogi-ddaedo giljabiga ita

There is a queen bee among the bees as there is a guide among a flock of geese.

Meaning: Every group has a leader

2. 벌둥지를 쑤셔 놓은것 같다. (NS)

Beol-doongji-leul ssoosyeo noeun geot gata

It is like stirring up a bee's nest.

Meaning: A chaotic, noisy, disorganized, and unruly situation.

3. 벌둥지 쑤셔놓은듯 하다. (NS)

Beol-doongji ssoosyeo noeudeud-hada

Like stirring up a bee's nest.

Meaning: very loud, disorderly, chaotic behavior.

4. 벌집보고 꿀돈내여 쓴다. $(\mathrm{N})$

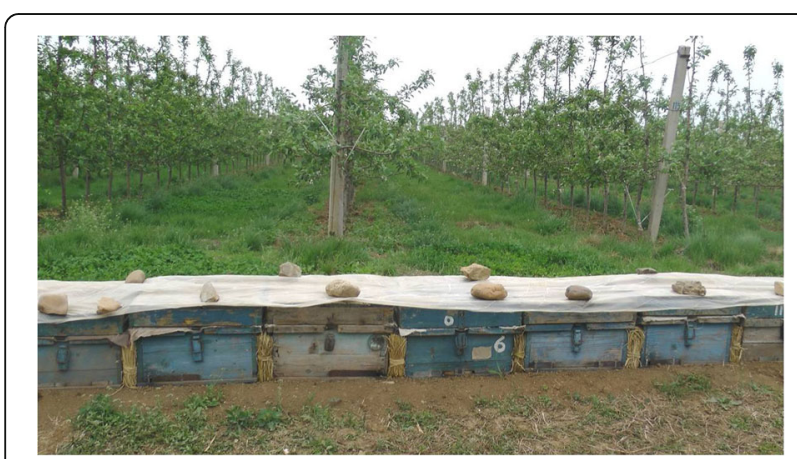

Fig. 5 At North Korea's Taedonggang Fruit farm more than 3,400,000 apple trees are grown on an area of 1026 ha. To pollinate the apple flowers up to 3000 portable, wooden-framed bee hives (with approximately 20,000 bees per colony), controlled by 100 beekeepers, are distributed around the farm. Photo credit: the author
Beol-jib bogo kkooldon naeyeo sseunda

Once you gaze at the honey bee's nest, you already borrowed some honey.

Meaning: Someone making a hurried decision; jumping to conclusions too hastily.

5. 벌 쐰 사람같다. (NS)

Beol ssoen saram gata

Like a person who got stung by a bee.

Meaning: A person who has suffered some mishap.

6. 꿀은 달아도 벌은 쏜다. (Ns)

Ggooleun dalado beoleun ssonda

Honey is sweet, but honey bees sting.

Meaning: Beware of the potential danger that is lurking.

8. 꽃이 향기로우면 벌과 나비가 날아든다. (NS)

Kkochi hyangiroumyeon beolgoa nabiga naradeunda

Bees and butterfly fly to fragrant flowers.

Meaning: Pretty women cannot fail to attract all kinds of menfolk.

Note: the $(\mathrm{N})$ and $(\mathrm{NS})$ behind each proverb indicate that the saying is found mainly restricted to North Korea (N) or is used and known to people of North as well as South Korea (NS).

\section{Conclusion}

This small collection of bee-related stories and sayings in a few selected Asian and Australian communities shows how bees have entered into the humans' awareness of thought and judgement. Seemingly widely neglected in the past by ethnographers and cultural anthropologists, attention to references of bees in different cultural, linguistic, and ethnic groups can be highly informative and illuminate attitudes of admiration, fear, ignorance, or even revulsion towards these insects.

As honey bees (and other insects) begin to become less and less a feature of the urban landscape, residents will become increasingly alienated from these insects-and to record and document references to them in myths, stories, proverbs, and idioms will become more and more difficult in the future. So as not to lose this aspect of a culture and its connection with the world of insects around them, a plea is made to collect whatever information is still available and to compare uses and references between different regions. This would support other fields of research aiming to discover and describe cultural relationships, migrations, and connections between different peoples in the Asian and Australian region.

\section{Abbreviations}

N: North Korea; NS: North and South Korea; S: South Korea

\section{Acknowledgements}

The author is indebted to his colleagues Drs. S. Changkija, K. Megu, S. Jugli, and L. Mozhui in India, Ph.D-student Kotaro Osawa in Japan, and undergraduate students of Pyongyang University of Science and Technology 
in North Korea (DPRK) for providing relevant information. The author gratefully acknowledges the support he was given to work on this project through a grant received by Professor Chuleui Jung via the Basic Science Research Program of the National Research Foundation of Korea (NRF), funded by the Ministry of Education (NRF-2018R1A6A1A03024862).

\section{Author's contributions}

The single author VBM-R is solely responsible for the study. The author(s) read and approved the final manuscript.

\section{Funding}

Support to publish this report came from Professor Chuleui Jung via the Basic Science Research Program of the National Research Foundation of Korea (NRF), funded by the Ministry of Education (NRF-

2018R1A6A1A03024862)

\section{Availability of data and materials}

Original material and additional data and photographs are available from the author on request.

\section{Declarations}

\section{Ethics approval and consent to participate}

Permission from the interviewees to use their answers was obtained. The study did not involve animal or human tissue. No reference number was issued.

\section{Consent for publication}

Consent for publication was obtained from the interviewees.

\section{Competing interests}

The author declares no competing interests.

Received: 1 November 2021 Accepted: 19 November 2021 Published online: 07 December 2021

\section{References}

Anonymous 2014. Mead lore and history. http://www.mountaindragonmazery. com/meadlore.html (Accessed 6 Aug 2021).

Anonymous 2021. Bees and honey in ancient India; 2021. https://docplayer. net/32260991-Bees-and-honey-in-ancient-india.html; (Accessed 5 Aug 2021). https://doi.org/10.1002/bmc.5285.

Berndt RM, Berndt CH. The world of the first Australians, Ure Smith, Sydney (Australia); 1964.

Borst P. The origin and distribution of honey bee. Am Bee J. 2015;161:565-8. Briggs, H. How flowering plants conquered the world. 2018. https://www.bbc com/news/science-environment-42656306; (Accessed 22 August 2021).

Cailloce, L. Of bees and men. CNRS Lejournal/News. 2019. https://news.cnrs.fr/a rticles/of-bees-and-men; (Accessed 3 July 2021)

Cridland JM, Tsutsui ND, Ramirez SR. The complex demographic history and evolutionary origin of the Western honey bee Apis mellifera. Genome Biol Evol. 2017;9(2):457-72. https://doi.org/10.1093/gbe/evx009.

Culliney TW. Origin and evolutionary history of the honey bees Apis. Bee World. 1983;64(1):29-38. https://doi.org/10.1080/0005772X.1983.11097905.

Engel MS. The taxonomy of recent and fossil honey bees (Hymenoptera: Apidae: Apis). J Hymenoptera Res. 1999:8:165-96.

Garnery L, Cornuet JM, Solignac M. Evolutionary history of the honey bee Aps mellifera inferred from mitochondrial DNA analysis. Mol Ecol. 1992; 1(3):145-54. https://doi.org/10.1111/j.1365-294X.1992.tb00170.x.

Jung C. A note on the early publication of beekeeping of Western honeybee, Apis mellifera, in Korea: Yangbong Yoji (AbrissBienenzucht) by P. Canisius Kugelgen. J Apiculture. 2014;29(1):73-7.

Kotthoff U, Wappler T, Engel MS. Greater past disparity and diversity hints at ancient migrations of European honey bee lineages into Africa and Asia. J Biogeography. 2013;40(10):1832-8. https://doi.org/10.1111/jbi.12151.

Kritsky G. The quest for the perfect hive: ancient Mediterranean origins. In: Hatjina F, Mavrofridis G, Pul JR, Hellenic, editors. Beekeeping in the Mediterranean from antiquity to the resent. Athens: Agricultural Organization "Demeter"; 2017. p. 50-6. https://doi.org/10.1645/21-51.
Manning FJ. Recent and fossil honey bees: some aspects of their cytology, phylogeny and evolution. Proc Linnean Society (Lond.). 1952;163(1):3-8. https://doi.org/10.1111/j.1095-8312.1952.tb00626.x.

Megu K, Chakravorty J, Meyer-Rochow VB. An ethnographic account of the role of edible insects in the Adi tribe ofArunachal Pradesh, North-East India. In: Halloran A, Vantomme P, Roos N, editors. Edible insects in sustainable food systems. Cham: Springer Publ.; 2018. p. 35-54.

Meyer-Rochow VB. Information on therapeutically as well as nutritionally important terrestrial arthropods in North Korea and an examination of the idiomatic roles insects play in North Korean proverbs and sayings. In: Harrison M, editor. North Korea-Political, Economic and Social Issues. New York: Nova Science Publishers; 2016. p. 169-85. https://doi.org/10.3390/ foods 10051036.

Meyer-Rochow VB, Kejonen A. Insects that inspired german and finnish insect idioms that affected human attitudes towards insects. Entomologie Heute. 2021:32:61-74.

Neige P. Events of increased biodiversity: evolutionary radiations in the fossil record. Chapter 4.3.1: In search of the first flower: ISTE-Press Ltd, Elsevier Publ.; 2015. https://doi.org/10.1093/cercor/bhab246.

Pawley A, Bulmer R. A dictionary of Kalam with ethnographic notes. Canberra (Australia): Pacific Linguistics, College of Asia and the Pacific, Australian National University Publ.; 2011.

Roffet-Salque M, Regert M, Evershed RP, Outram AK, Cramp LJE, Decavallas O, et al. Widespread exploitation of the honeybee by early Neolithic farmers. Nature. 2016;527(7577):226-30. https://doi.org/10.1038/nature15757.

Spencer B, Gillan FJ. The native tribes of Central Australia. London: Macmillan; 1899.

Tihelka E, Cai C, Pisani D, Donoghue PCJ. Mitochondrial genomes illustrate the evolutionary history of the Western honey bee (Apis mellifera). Scientific Rep. 2020;10(1):14515. https://doi.org/10.1038/s41598-020-71393-0.

Walberg A, Han F, Wellhagen G, Dohle B, Kawata M, et al. A worldwide survey of genome sequence variationprovides insight into the evolutionary history of the honey bee Apis mellifera. Nat Genet 2014. 2014;46(10):1081-8. https:// doi.org/10.1038/ng.3077.

Whitfield CW, Behura SK, Berlocher SH, Clark AG, Johnston JS, Sheppard WS, et al. Thrice out of Africa: ancient and recent expansions of the honey bee Apis mellifera. Science. 2006;314(5799):642-5. https://doi.org/10.1126/ science.1132772.

Wilson EO. The insect societies. Cambridge: Belknap Press; 1971. https://doi.org/1 0.1111/j.1749-6632.1971.tb13548.x.

\section{Publisher's Note}

Springer Nature remains neutral with regard to jurisdictional claims in published maps and institutional affiliations.

Ready to submit your research? Choose BMC and benefit from:

- fast, convenient online submission

- thorough peer review by experienced researchers in your field

- rapid publication on acceptance

- support for research data, including large and complex data types

- gold Open Access which fosters wider collaboration and increased citations

- maximum visibility for your research: over $100 \mathrm{M}$ website views per year

At $\mathrm{BMC}$, research is always in progress.

Learn more biomedcentral.com/submissions 